\title{
SLC28A1 wt Allele
}

National Cancer Institute

\section{Source}

National Cancer Institute. SLC28A1 wt Allele. NCI Thesaurus. Code C96050.

Human SLC28A1 wild-type allele is located in the vicinity of $15 q 25.3$ and is approximately

$61 \mathrm{~kb}$ in length. This allele, which encodes sodium/nucleoside cotransporter 1 protein, plays a role in the modulation of nucleotide and nucleoside transport. 